and not to pericaecal inflammation. Not only did he give a clear description of the pathological and clinical features of appendicitis but he also pointed out the advisability of surgical treatment ${ }^{1}$ :

If, after the first 24 hours from the onset of the severe pain, the peritonitis is evidently spreading, and the condition of the patient is grave, the question should be entertained of an immediate operation for exposing the appendix and determining its condition with reference to its removal. If any good results are to arise from such treatment it must be applied early.

His summary is as true today as when first written:

In conclusion, the following statements seem warranted: The vital importance of the early recognition of perforating appendicitis is unmistakable. Its diagnosis, in most cases, is comparatively easy. Its eventual treatment by laparotomy is generally indispensible. Urgent symptoms demand immediate exposure of the perforated appendix, after recovery from the shock, and its treatment according to surgical principles. If delay seems warranted, the resulting abscess, as a rule intraperitoneal, should be incised as it becomes evident. This is usually on the third day after the appearance of the first characteristic symptom of the disease.

\section{Reginald Fitz}

Reginald Fitz was born in 1843 in Chelsea, Massachusetts. He graduated from Harvard and studied in Vienna with Rokitansky and Skoda and in Berlin with Virchow. By the age of 35 he was professor of pathological anatomy at Harvard and in charge of the pathology laboratory at Massachusetts General Hospital. It was there that his classical studies on appendicitis were carried out. In 1887 he became a visiting physician at Massachusetts General Hospital, and at the age of 49 he became professor of medicine at Harvard. He died in 1913 at the age of 70 . Today he should be remembered not only for his work on appendicitis but for his equally valuable work on the clinical features and pathological changes of acute pancreatitis.

\section{References}

1 Fitz HR. Perforating inflammation of the vermiform appendix; with special reference to its early diagnosis and treatment. Trans Assoc Am Physicians 1886;1:107-36. 2 Cope Z. A history of the acute abdomen. London; Oxford University Press, 1965.

\title{
Saint Who's?
}

\section{JOHN DEWHURST}

By my last reckoning there were 160 hospitals in Britain named after a saint. St Mary has easily the largest number (26) with St John (13) in second place and St George and St Luke jointly third, with nine each. Others are St Andrew and St Michael (six each); Anne, Margaret, James, and Peter (five each); Paul and David (four each); Nicholas, Thomas, Clement, Lawrence, Leonard, and Catherine (three each); Matthew, Stephen, Bartholomew, Francis, Joseph, and Martin (two each). Thirty two saints patronise just one hospital-Aldhelm, Anthony, Audrey, Augustine, Barnabus, Blazey, Cadoc, Chad, Charles, Christopher, Crispin, Ebba, Editha, Edmund, Edward, Faith, Giles, Helen, Helier, Hilda, Mark, Monica, Olave, Oswald, Pancras, Philip, Saviour, Theresa, Vincent, Wilfrid, Woolas, and Wulstan.

These simple facts give us considerable opportunity for speculation. When there are several saints with the same name which is the one concerned? Why was he or she chosen? Does the saint have any special medical connection? And who were some of the saints on the list with unfamiliar names?

It seems a reasonable assumption that most if not all the St Marys refer to the Blessed Virgin, pre-eminent among the saints although with no medical association; St Mary Magdalene is a possibility for one or two but she has no medical association either.

There are three main contenders for the hospitals named St John. Either the Baptist or the Evangelist may be intended but St John of God is a strong candidate although he is usually given his complete title to distinguish him from the other two. He was a fifteenth century Portuguese who fought for years in the Spanish army before becoming fired with religious zeal. Unable to reach north Africa, where he hoped to die a martyr's death ransoming slaves, he became a highly successful seller of religious books and pictures. Then he

\section{Iver, Bucks SL0 9DY}

SIR JOHN DEWHURST, FRCOG, FRCSED, emeritus professor of obstetrics and gynaecology, University of London

Correspondence to: Glendale House, 39 Old Slade Lane, Iver, Bucks SL0 9DY. went mad, gave away his books, and ran wildly through the streets. Eventually he recovered and devoted the rest of his life to helping the sick.

\section{Patroness of childbirth}

Several St Margarets contest the five hospitals with this name but the favourite is St Margaret of Antioch. She was a mythical figure whose legend tells of her refusal to marry the pagan governor of Antioch since she was an avowed Christian virgin. She was tortured in a variety of ways and at one point was swallowed by a dragon which found her indigestible and burst asunder. She became the patroness of childbirth because of a promise made before she died that women who invoked her would be safe during pregnancy and labour. The Holy See suppressed her cult in 1969 but her name lives on. One St Margaret's Hospital, however, in Auchterarder, Scotland, surely suggests a dedication to St Margaret of Scotland, grand daughter of Edmund Ironside and Queen to King Malcolm III. She was a woman of saintly behaviour and disposition who bore her husband eight children. One of them, King David of Scotland, also became a saint, but it seems unlikely that any of the four hospitals which bear that name refer to him. All are in Wales and are surely named after the patron saint of that country who flourished in south Wales in the sixth century.

We have only one small clue to suggest which St James-James the Greater or James the Less-deserves the title to four hospitals. James the Greater used to be invoked for the cure of rheumatism although there is nothing in his life or legend to suggest that he suffered from it.

Three hospitals are named St Thomas but after whom-St Thomas the Apostle, Thomas Aquinas, Thomas of Canterbury, or even Thomas of Hales or Thomas of Hereford? If we are to be guided by medical considerations the apostle and Thomas Becket are the favourites. St Thomas, the twin, who refused to believe in the risen Lord until he could put his finger in the marks of the nails and his hand in Christ's side, used to be invoked for the cure of blindness and eye disorders because of the spiritual blindness he showed on that occasion. In this sense, therefore, we might regard 


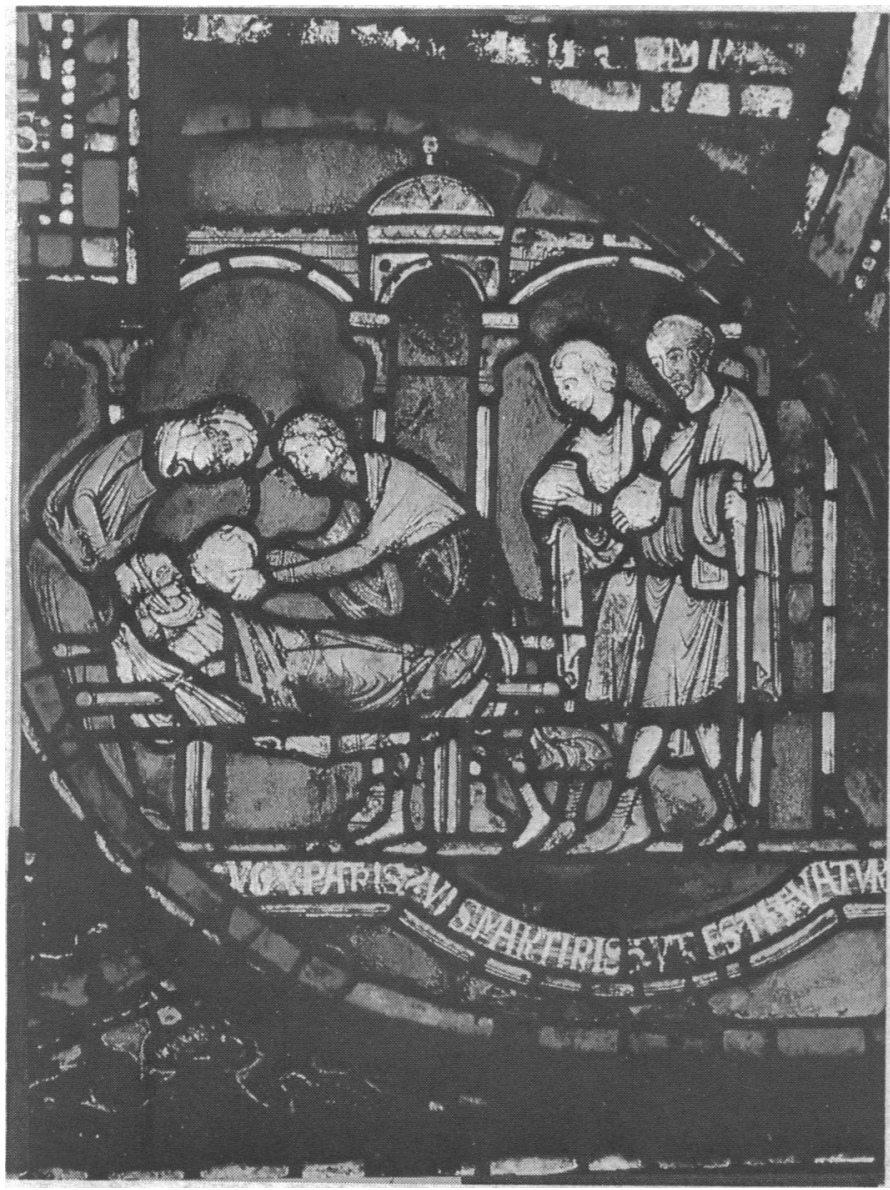

FIG 1-Stained glass window in the Trinity Chapel, Canterbury Cathedral, depicting a sick boy drinking the water of St Thomas. From The Pilgrims' Way by John Adair and Peter Cheze Brown.

him as a specialist but St Thomas of Canterbury was clearly a general practitioner since a prodigious number of cures from a wide variety of disorders were attributed to drinking the water of St Thomas (fig 1) - a large volume of water into which had been sprinkled tiny particles of the dried blood of the saint.

St Catherine of Alexandria is more likely to be intended as patron of three hospitals bearing her name than St Catherine of Genoa or of Siena. Like Margaret of Antioch, Catherine of Alexandria was a mythical figure whose cult was also suppressed by the Holy See in 1969. Her legend tells that she, like Margaret, refused to marry a high ranking pagan suitor since she had dedicated her life to Almighty God. Fifty philosophers were called in to show her the error of her Christian ways but she confounded them and many who heard the debate became Christian. She was condemned to die on a huge spiked wheel (the Catherine wheel of 5 November) but the wheel collapsed killing her torturers, and thousands more became Christians (fig 2). Finally, she was beheaded when milk-the milk of human kindness-spouted from her body instead of blood, leading to her patronage of nurses.

The search for a specific medical connection in the many other hospital patrons reveals surprisingly few-Anthony, Chad, Christopher, Edmund, George, Giles, Leonard, Luke, and Oswald.

\section{St Anthony of Egypt or of Padua?}

Two St Anthonys, each with a medical association, contest one hospital at Cheam. St Anthony of Egypt was the archetypal desert hermit who gave away all his money and lived in solitude, enduring formidable privations and temptations until his death at the age of 99. Ergot poisoning was once called St Anthony's fire, an association which came about because, in the Middle Ages, the monks of the

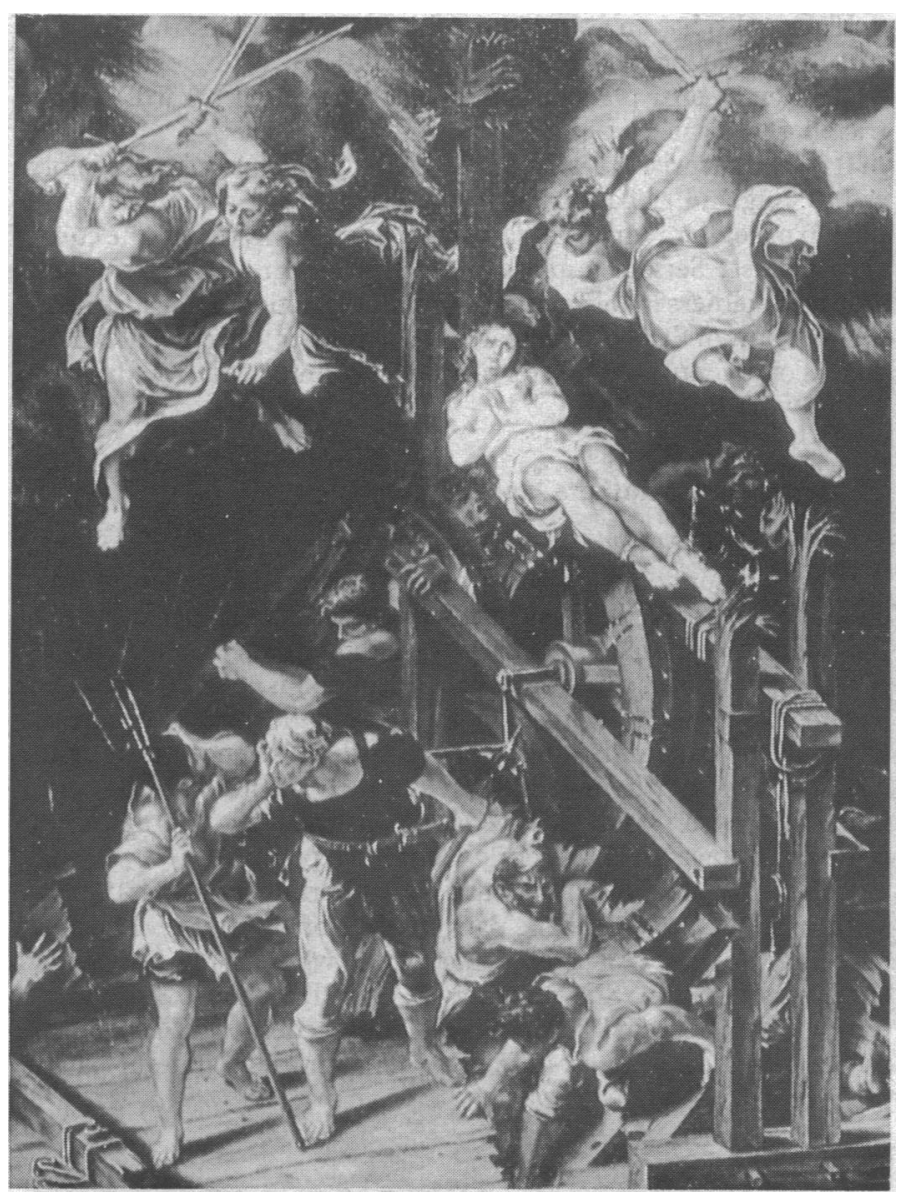

FIG 2-St Catherine of Alexandria, patroness of nurses, by Orsi. Angels have come to her aid and the wheel of torture is collapsing. From Saints, their Cults and Origins by Caroline Williams.

Order of Hospitallers of St Anthony opened hospitals with red painted walls for sufferers from the disease, in which affected fingers and toes burn like fire. The original name was holy fire (ignis sacer) before St Anthony had his name attached. Representations of the saint show him with a bell, denoting his hermit status, and a pig (fig 3 ) since the monks of the order were allowed to let their pigs roam the streets. St Anthony of Padua, famous as a finder of lost articles, used to be invoked also for the cure of infertility, an association hard to understand. But which is patron of Cheam Hospital?

An equally puzzling link with infertility is found in St Edmund who was also invoked by barren women. He was King of the East Angles and was martyred by the Danes in 869 . On 20 November, his feast day, it was at one time the custom for infertile women to walk alongside a white bull stroking its flanks until they reached the monastery gates when the women went inside to the saint's shrine to offer prayers that they might conceive. But this does not explain why St Edmund's Hospital is in Northampton.

More geographically appropriate is a hospital named after St Chad, the first Bishop of Lichfield, in Birmingham. It is also medically appropriate since, in former times, pilgrims visiting his shrine could put their hands through a little aperture in the wall, take some of the dust from within, sprinkle it into water, and give it to an invalid to drink with every expectation of cure.

We have seen a similar condition already with the water of St Thomas and we meet it again with St Oswald who has a hospital at Ashbourne. Oswald, King of Northumbria, was killed fighting the heathen King of Mercia, Penda, in 642. The Venerable Bede describes several miracles of healing near his grave and the cure of a man from the plague after he had drunk water into which had been placed a fragment of the stake which had impaled the severed head of the saint. 
Plague also has an association with St Christopher, the patron of travellers who has a hospital at Fareham. He used to be invoked for protection against plague, tempest, and flood, all hazards which a traveller in former times could expect to encounter.

It is not surprising that all nine hospitals named after St George are in England. Apart from being the national patron he is also patron of soldiers which explains why he was invoked for the cure of skin disease. Serious cutaneous sores and skin eruptions severely troubled soldiers in former times so the association is not surprising. All we know of St George is that he was a soldier killed in Palestine in the second century. The story of his encounter with the dragon is entirely mythical.

\section{Lepers, nursing mothers, and cripples}

St Giles has, nowadays, only one hospital dedicated to him and that is in London. At one time, however, when lepers were common, leper hospitals were named after him. He is patron saint of the unlikely combination of lepers, nursing mothers, and cripples, perhaps one reason why his church in London is at Cripplegate. His legend tells, how, while living in the forest in the south of France, he was fed for a time by the milk of a hind-hence the nursing mothers. One day a hunting party pursued the hind and an arrow intended for it wounded the saint instead (fig 4)-hence the cripples. But we are in the dark about the lepers.

St Leonard, like St Giles, was a forest hermit, in which unlikely setting he became one of the patron saints of childbirth. The story goes that he was visited by King Clovis whose wife, heavy with child, was with him. She was safely delivered, thanks to St Leonard, but whether he acted as midwife or interceded with God on her account we do not know. He got a most original grateful patient present none the less-as much land as he could ride round in one night on a donkey. The animal covered so much ground that the saint was able to build the Abbey of Noblac on it.

We know from St Paul's Epistle to the Colossians that St Luke was a physician - the only one among the group of hospital patrons. Strangely he is almost always shown in hagiographic art in another guise-painting a picture of the Blessed Virgin with his emblem, an ox, close by (fig 5). He is of course one of the patron saints of doctors but artists claim him as their patron also.

We will find few medical connections among the other patrons. Some have a simple geographical connection with a local saint. Frome, for exampe, has St Aldhelm's Hospital named for an abbot of Malmesbury and bishop of Wessex who died in 709; St Blazey, an early Cornish saint, has a hospital at Par bearing his name; St Cadoc, a sixth century saint from south Wales has a hospital at Caerleon, and his father, St Woolas, one at Newport; St Wulstan, the eleventh century Bishop of Worcester, has a hospital at Malvern, St Augustine, one at Canterbury, and St Hilda, abbess of a nunnery at Hartlepool in the seventh century has a hospital there; St Edith, or Editha, of Polesworth has given her name to a hospital at nearby Tamworth and St Wilfred to one at Ripon where he was abbot in the seventh century.

There are some patronages, however, which defy any such geographical explanation. Why does St Helier, the first martyr of Jersey, have a hospital in London; St Ebba, who was abbess of the nunnery of Coldingham on the remote Northumbrian coast, one at Epsom; or St Edmund of the East Angles one at Northampton?

Northampton, however, has one of the most delightfully original dedications in St Crispin's Hospital. The town is famous for its shoes and St Crispin and his brother St Crispinian are the patron saints of shoemakers since, to avoid taking alms from those to whom
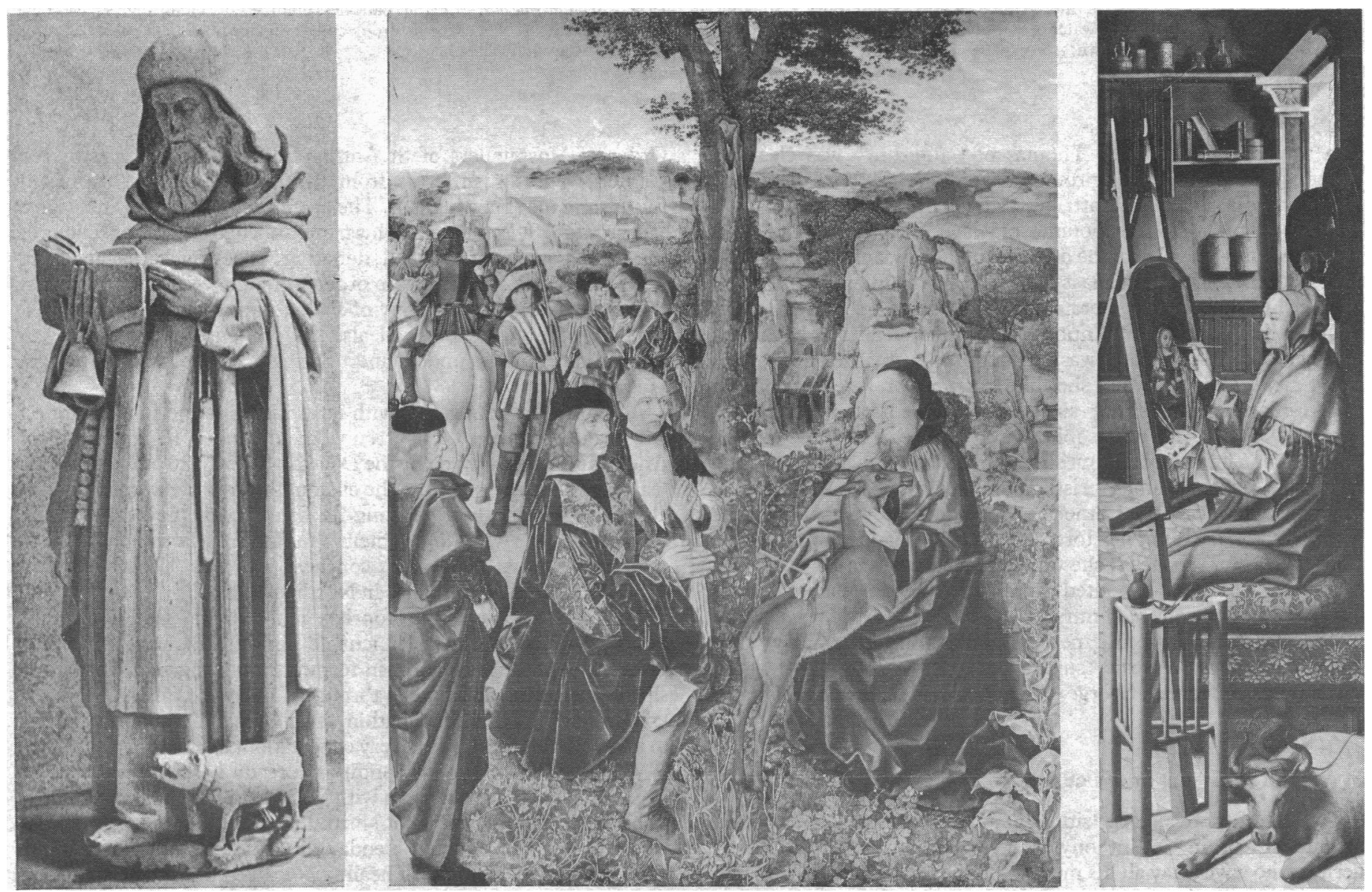

FIG 3 (left)-St Anthony of Egypt. Henry VII's Chapel, Westminster Abbey. (By courtesy of the Dean and Chapter of Westminster.) FIG 4 (centre)-St Giles and the hind by the Master of St Giles. (By courtesy of the Trustees, The National Gallery, London.) FIG 5 (right)-St Luke painting the Virgin and Child by a follower of Quinton Massys. (By courtesy of the Trustees, The National Gallery, London.) 


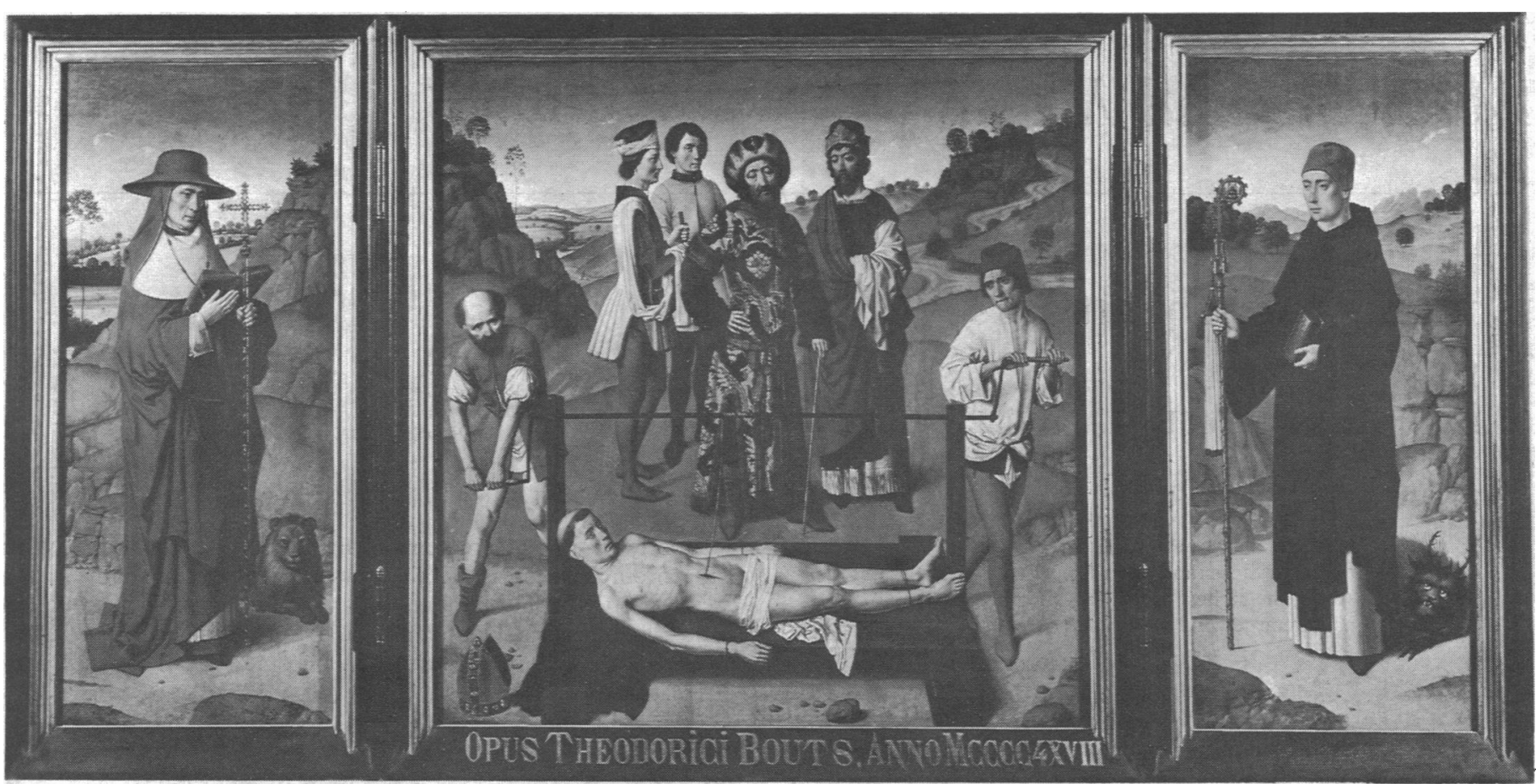

FIG 6-St Elmo by Dieric Bouts, c 1415-75. Copyright A C L Brussels.

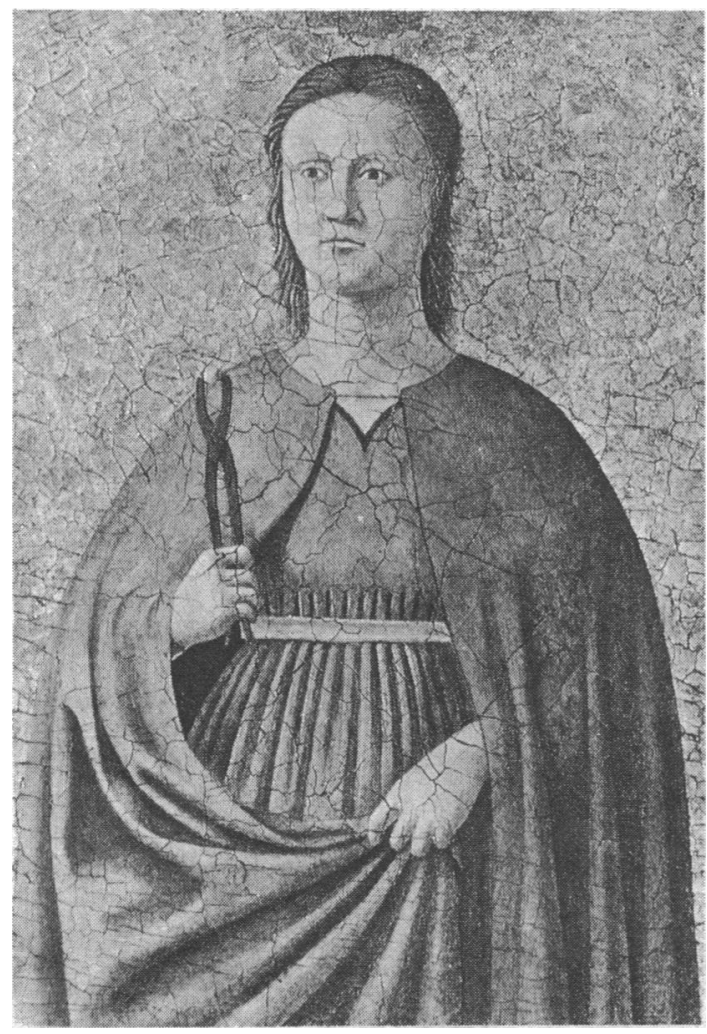

FIG 7-A defiant St Appollonia, patron saint of toothache sufferers, brandishing her emblem, a pair of tongs. From Signs and Symbols in Christian Art by George Ferguson.

they preached, they supported themselves by their trade as cobblers.

With this ingenious dedication in mind is, it too much to hope that future National Health Service hospitals - if any are built-might be more suitably named? Surely we need a children's hospital named after St Elmo (fig 6) invoked for the cure of colic in children in the mistaken belief that he was martyred by having his intestines wound on to a windlass; and ear, nose and throat hospital named for St Blaise, the patron saint of throats; a mental hospital for St Vitus, invoked for the cure of mental disorder, epilepsy, and possession by devils; a cancer hospital called after St Peregrine, a thirteenth century monk miraculously cured from a repulsive cancer on his foot the night before he was to have it amputated; an eye hospital called after St Lucy the principal patron of the blind; and a dental hospital for St Apollonia (fig7) invoked for the cure of toothache.

And if the acquired immune deficiency syndrome (AIDS) ever becomes the scourge many fear and a hospital is built for its sufferers may it please be called St Fiacre's Hospital? St Fiacre was a sixth century Irish missionary who went to Gaul where he set up a hospice for the poor and sick but would never let a woman enter it. He was invoked for the cure of venereal disease.

\section{Relationships in farmyards}

Bereavement reactions are generally associated with "loss" by death of a family member or family pet especially a dog.

Recently I have met farmers who have become depressed after the sale of cows to the local mart. Many doctors may not realise it but there is an intimate relationship and bond between the farmer and his cow. A cow is reared and given a name; she may only allow the farmer to hand milk her; he worries about her when she is "in calf" or develops mastitis; and she is cared for like a family pet. Some of the farmers become upset at the thought of selling their cows to the factory for slaughter.

I am looking further into this relationship and wonder if any other doctors have come across similar instances with non-domesticated animals such as horses, pigs, and greyhounds. Also, with the present emphasis on ethology in psychiatry maybe we could understand human behaviour better by studying more animals in the farmyard than in laboratories or zoos.

\section{BHAMJEE}

Mid-Western Health Board,

Our Lady's Hospital,

Ennis,

County Clare 